(C) В.А. Гусєв, I.М. Дударєв, д.т.н.

Луцький національний технічний університет

Токарчук М.В.

Любешівський технічний коледж Луцького національного технічного університету

\title{
ОГЛЯД КОНСТРУКЦІЙ СЕПАРАТОРІВ СИПКИХ МАТЕРІАЛІВ
}

У статті розглянуто способи сепарування сипких матеріалів та визначено властивості матеріалів, на яких вони засновані, також представлено конструкції решітчастих сепараторів. Запропоновано класифікацію решітчастих сепараторів сипких матеріалів.

СЕПАРАТОР, СЕПАРУВАННЯ, СИПКИЙ МАТЕРИАЛ, КЛАСИФІКАЦІЯ СЕПАРАТОРІВ

Постановка проблеми. У сільському господарстві, переробній та харчовій промисловості широко розповсюджений 
процес розділення сипких матеріалів на фракції або сепарування суміші на компоненти. Для здійснення сепарування використовують спеціалізоване обладнання - сепаратори, які розрізняють як за способом сепарування, так і за конструкцією. Сепарування можливе, якщо фракції сипкого матеріалу або компоненти суміші мають відмінні геометричні параметри, фізикомеханічні або аеродинамічні властивості, зокрема, відмінні розміри або форма частинок матеріалу чи компонентів, їх маса, фрикційні властивості, електропровідність тощо. Як правило, сепаратори реалізують одночасно або послідовно декілька способів сепарування для покращення поділу сипкого матеріалу на фракції або суміші на компоненти. Таким чином, для вибору найбільш придатного способу сепарування та конструкції сепаратора для сипкого матеріалу чи суміші з певними властивостями, необхідно здійснити огляд конструкцій сепараторів сипких матеріалів. Тому дослідження у цьому напрямку є актуальними.

Аналіз останніх досліджень i публікацій. Розробці методів сепарування сипких матеріалів та обгрунтуванню конструкцій сепараторів присвячені роботи багатьох вітчизняних та закордонних науковців [1-8]. Також у роботах науковців представлені класифікації сепараторів сипких матеріалів. Разом 3 тим, поява нових конструкцій зумовлює необхідність їх аналізу та розширення класифікації сепараторів.

Мета дослідження - здійснити огляд конструкцій сепараторів сипких матеріалів та розробити їх класифікацію.

Результати дослідження. Серед способів сепарування сипких матеріалів розрізняють: сепарування за масою; сепарування за розміром; сепарування за формою; сепарування за фрикційними властивостями; сепарування за аеродинамічними властивостями.

Найбільш поширеними способами $\epsilon$ сепарування за розмірами та за аеродинамічними властивостями. Ці властивості $\epsilon$ добре вивченими i більшість сучасних сепараторів, зокрема зерноочисних, мають повітряно-решітно-трієрні робочі органи. Для інтенсифікації процесу сепарування сипких матеріалів використовують сепаратори із коливними робочими поверхнями. Коливання робочих поверхонь сприяє розшаруванню матеріалу та проходженню частинок матеріалу меншого розміру (компонентів суміші) із верхніх шарів матеріалу до перфорованих робочих поверхонь.

У відповідності до способів сепарування, конструкції сепараторів можна розділити на три групи: 
1. Сепаратори, принцип роботи яких заснований на урахуванні однієї властивості сипкого матеріалу, наприклад, сепаратори, робочим органом яких $є$ решета із круглими отворами, трієри тощо (рис. 1, а).

2. Сепаратори, в яких сепарування сипкого матеріалу (суміші) здійснюється послідовно за двома або кількома властивостями, тобто комплексом фізико-механічних властивостей, наприклад, решето-трієрна машина (рис. 1, б).

3. Сепаратори, у яких під час сепарування враховується комбінація властивостей сипкого матеріалу (суміші) одночасно на одному робочому органі (поверхні), тобто сепарування одночасно здійснюється за сукупністю фізико-механічних властивостей. До таких сепараторів можна віднести, наприклад, вібраційні сепаратори із фрикційними неперфорованими поверхнями (рис. 1, в).

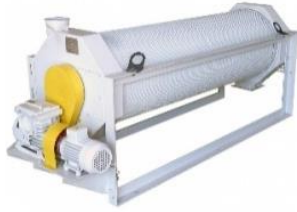

a

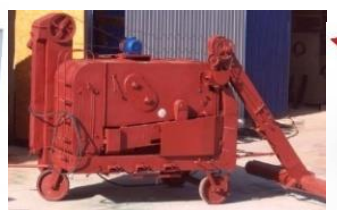

6

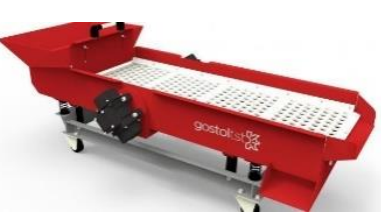

B

Рис. 1 - Конструкції сепараторів: а - трієр БТХМ; б - решетотрієрна машина CM-4; в - вібраційний сепаратор Gostol TST

У сільському господарстві, переробній та харчовій промисловості найбільш поширені сепаратори, що здійснюють сепарування сипких матеріалів чи їх сумішей за однією властивістю, зокрема, розміром або формою. У цьому випадку, як правило, використовуються сепаратори із решітчастими робочими поверхнями. Розглянемо конструкції деяких решітчастих сепараторів.

Спіральний сепаратор, що представлений на рис. 2, містить диск, до якого прикріплено один (рис. 2, а, б) [9] чи декілька (рис. 2, в) [10] спіралеподібних двосекційних матеріалопроводи (рис. 2, г), які утворено внутрішньою та зовнішньою секціями. 


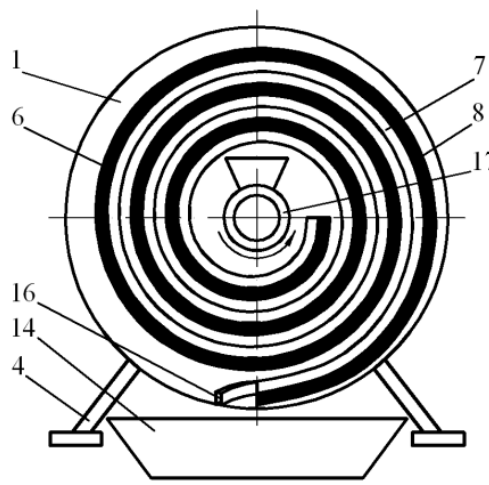

a

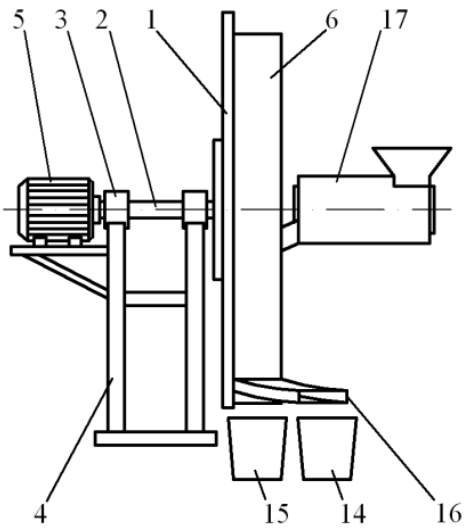

6

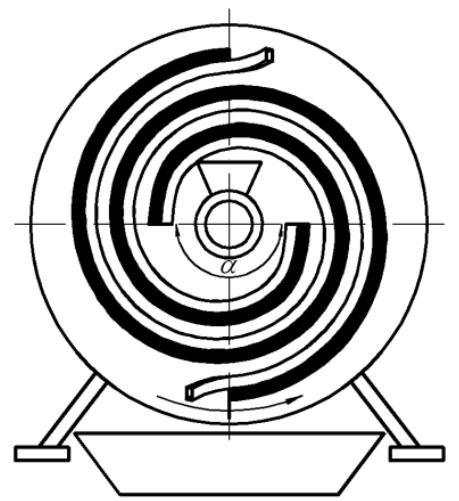

B

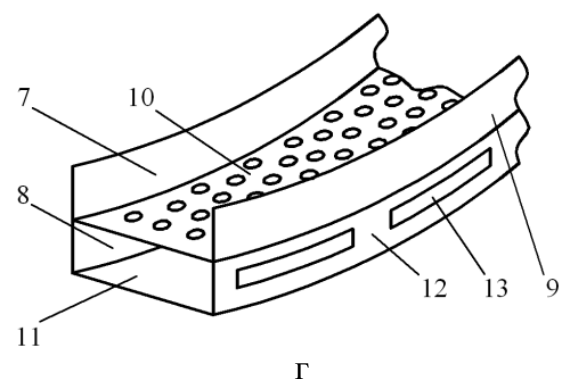

Рис. 2 - Спіральний сепаратор 3 одним (а), (б) та двома (в) матеріалопроводами (г) (1 - диск; 2 - приводний вал; 3 підшипникові вузли; 4 - рама; 5 - привод; 6 - матеріалопровід; 7 внутрішня секція; 8 - зовнішня секція; 9, 12 - обмежувальні боковини; 10 - спіральне решето; 11 - днище;13 - технологічні отвори; 14 - бункер для крупної фракції матеріалу; 15 - бункер для дрібної фракції матеріалу; 16 - вивантажувальний рукав; 17 - завантажувальний механізм)

Внаслідок обертання диска сипкий матеріал переміщається спіральним решетом внутрішньої секції. Під час переміщення решетом відбувається розділення сипкого матеріалу на дві фракції. Крупна фракція сипкого матеріалу залишається у внутрішній секції, 
а дрібна фракція проходить у зовнішню секцію, днищем якої рухається до останнього витка матеріалопроводу.

На рис. 3 представлена конструкція призматичного сепаратора [11], який містить раму та каркас. Каркас приводиться в обертальний рух від привода та виконаний у вигляді ребер горизонтально розміщеної правильної призми. До ребер каркаса із зовнішньої сторони кріпляться змінні решета, а із внутрішньої сторони кріпляться спрямовувачі. Каркас розташовано в кожусі, що кріпиться на рамі, у нижній частині кожуха передбачено жолоб 3 вивантажувальним шнеком.

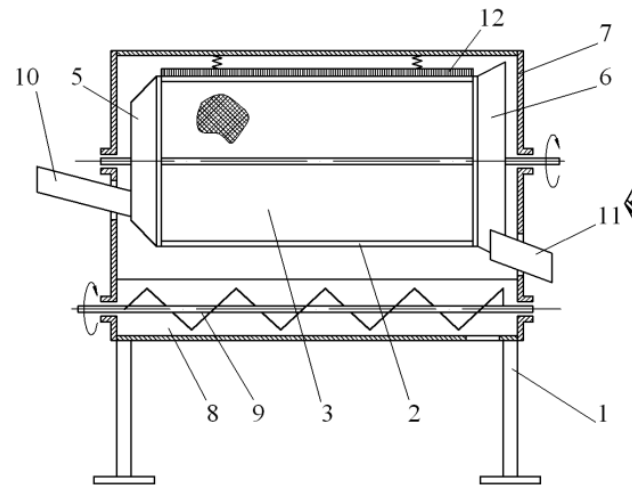

$\mathrm{a}$

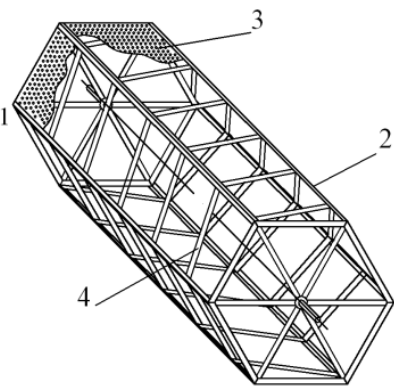

6

Рис. 3 - Призматичний сепаратор (а) та його каркас (б): 1 - рама; 2 каркас; 3 - решета; 4 - спрямовувачі; 5 - завантажувальна горловини; 6 - вивантажувальна горловина; 7 - кожух; 8 - жолоб; 9 - вивантажувальний шнек; 10 - завантажувальний лоток; 11 вивантажувальний лоток; 12 - чистик

Під час роботи призматичного сепаратор сипкий матеріал спрямовується на внутрішню поверхню змінних решіт. Під час обертання каркаса відбувається ковзання матеріалу поверхнями решіт та пересипання з одного на друге. У результаті цього, дрібна фракція матеріалу проходить через отвори в решетах, а крупна фракція рухається вздовж спрямовувачів внаслідок підпору наступних порцій матеріалу та вивантажується із призматичного сепаратора. Дрібна фракція вивантажується шнеком.

Пірамідальний сепаратор [12], що представлений на рис. 4, містить раму із чотирма опорами, дві з яких виконані з можливістю зміни довжини, на якій розташований кожух циліндричної форми. 
Всередині кожуха встановлено каркас, який виконаний у формі ребер зрізаної піраміди, а змінні решета, що кріпляться до ребер, $є$ іiі гранями. У нижній частині корпуса кожуха передбачено вивантажувальний шнек. Пірамідальний сепаратор може бути виготовлений із різною кількістю граней.

Під час роботи сепаратора сипкий матеріал спрямовується на внутрішню поверхню змінних решіт. Під час обертання каркаса відбувається ковзання матеріалу поверхнями решіт та пересипання 3 одного на друге. Внаслідок цього, дрібна фракція матеріалу проходить через отвори в решетах, а крупна фракція рухається вздовж осі обертання каркаса внаслідок підпору наступних порцій матеріалу та вивантажується із сепаратора через вивантажувальний лоток.

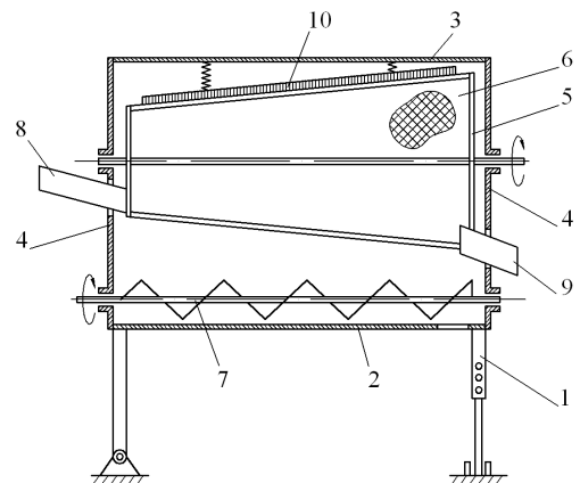

a

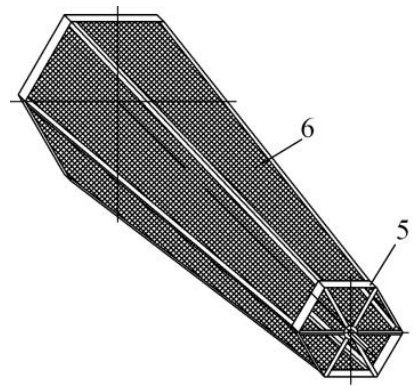

6

Рис. 4 - Пірамідальний сепаратор (а) та його каркас (б): 1 - рама; 2 - корпус; 3 - верхня кришка; 4 - торцева кришка; 5 - каркас; 6 - решета; 7 - вивантажувальний шнек; 8 - завантажувальний лоток; 9 - вивантажувальний лоток; 10 - чистик

Решітчасті сепаратори сипких матеріалів залежно від конструкції їх робочих поверхонь (решіт) та кількості можна класифікувати таким чином, як запропоновано на рис. 5. 


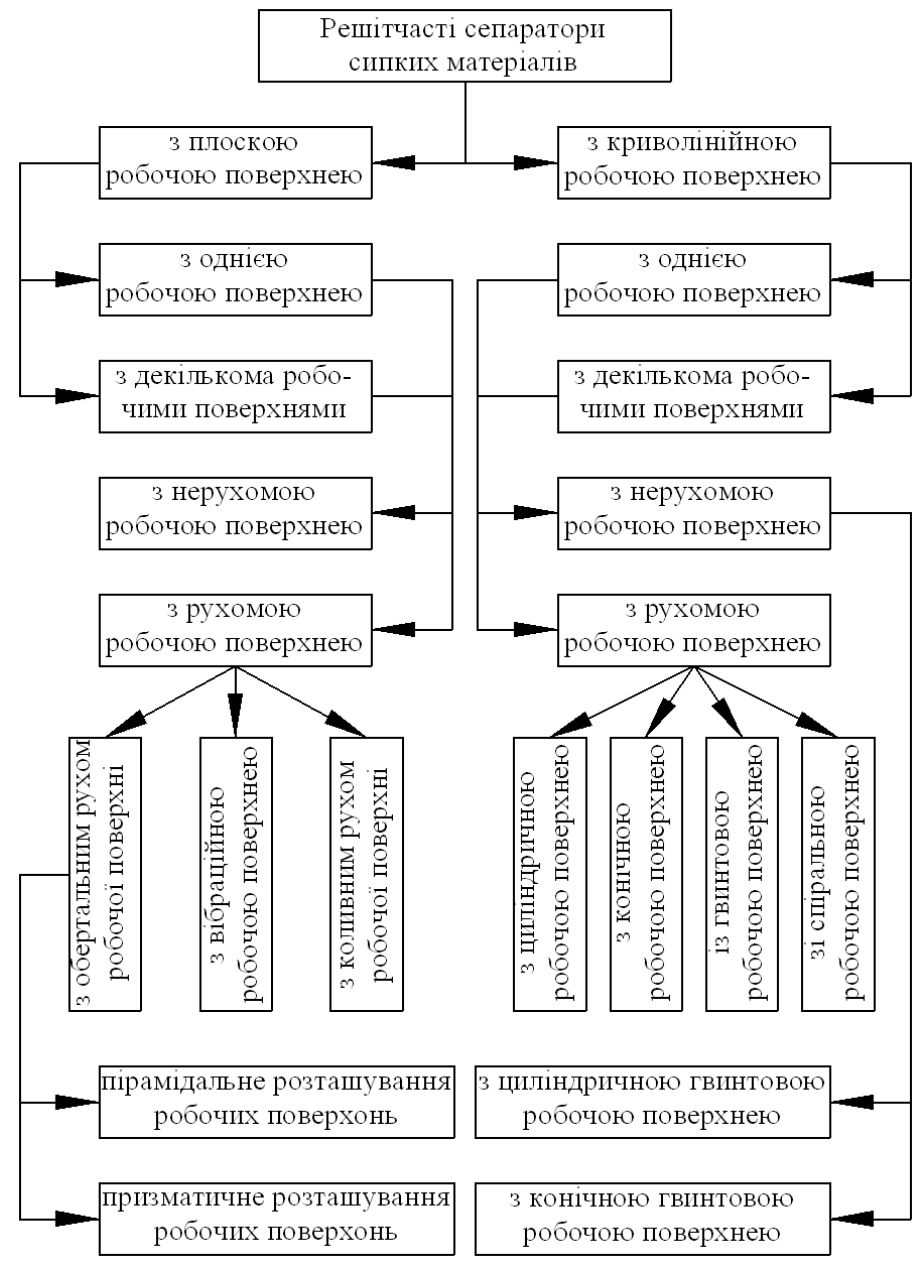

Рис. 5 - Класифікація решітчастих сепараторів сипких матеріалів

Висновоки. Спосіб сепарування сипких матеріалів та їх сумішей залежить від їх властивостей. Найбільш поширеним способом сепарування сипких матеріалів $\epsilon$ сепарування за розміром та формою. Цей спосіб реалізують на решітчастих сепараторах різних конструкцій. Огляд конструкцій решітчастих сепараторів дозволив запропонувати їх класифікацію. 


\section{Література}

1. Основы расчета и конструирования машин и автоматов пищевых производств: учеб. пособие для вузов / Соколов А.Я. [и др.]; [под ред. А.Я. Соколова]. - М.: Машиностроение, 1969. $637 \mathrm{c}$.

2. Заика П.М. Сепарация семян по комплексу физикомеханических свойств / П.М. Заика, Г.Е. Мазнев. - М.: Колос, 1978. $-287 \mathrm{c}$.

3. Карташевич С.M. Механико-технологические основы повышения эффективности механизированных комплексов для послеуборочной обработки зерна и семян (теория, расчет, результаты проектирования и испытания технологических комплексов): монография / С.М. Карташевич. - Минск: РУП “БелНИИагроэнерго”, 2001. - 288 с.

4. Богомолов О.В. Наукове обгрунтування енергозберігаючих процесів та обладнання для сепарації харчової сипкої сировини: автореф. дис. ...д-ра техн. наук: 05.18.12 / Богомолов Олексій Васильович; Харківський державний університет харчування та торгівлі. - Харків, 2006. - 34 с.

5. Чурин Ю.Г. Теория сепарации сыпучих материалов и ее применение при проектировании и эксплуатации промышленных сепараторов вибрационного типа: монография / Ю.Г. Чурин. Кострома: КГСХА, 2010. - 98 с.

6. Єрмак В.П. Класифікація засобів сепарації та конструкцій машин для відбору насіння з високими посівними властивостями / В.П. Єрмак, Є.В. Богданов, А.А. Ільченок // Збірник наукових праць Луганського національного аграрного університету. - № 35. - Серія (Технічні науки). - Луганськ: ЛНАУ. - 2012. - С. 127 - 132.

7. Фалько О.Л. Наукове обгрунтування процесу фракціонування рослинної сировини: автореф. дис. ...д-ра техн. наук: 05.18.12 / Фалько Олександр Леонідович; Національний університет харчових технологій. - Київ, 2014. - 46 с.

8. Дадак В.О. Обгрунтування параметрів та режимів роботи пневмосепаратора дрібнонасіннєвих сумішей: дис. ...канд. техн. наук: 05.05.11 / Дадак Віктор Олександрович; Львівський національний аграрний університет. - Львів, 2015. - 174 с.

9. Пат. №111203 Україна, МПК В07В13/11. Спіральний сепаратор / І.М. Дударєв; Заяв. 16.12.2013; опубл. 11.04.2016; Бюл. №7.

10. Пат. №111130 Україна, МПК А23N15/00, В09B1/00. Спіральний сепаратор / I.M. Дударєв; Заяв. 19.05.2014; опубл. 10.11.2016; Бюл. №21. 
11. Пат. №59337 Україна, МПК А23 N15/00. Призматичний сепаратор / I.M. Дударєв; Заяв. 01.11.2010; опубл. 10.05.2011; Бюл. №9.

12. Пат. №59339 Україна, МПК А23 N15/00. Пірамідальний сепаратор / I.M. Дударєв; Заяв. 01.11.2010; опубл. 10.05.2011; Бюл. №9. 